\title{
Educated and Competent Staff as Important Factor of Innovation Development of Machine- Building and Metalworking Industry in Latvia
}

\author{
Jelena Lukjanova ${ }^{1^{*}}$ Olena Sushchenko ${ }^{2}$ and Oleksandr Zyma ${ }^{3}$ \\ ${ }^{1}$ ISMA University, 1 Lomonosova Str., Bld.6, LV-1019, Riga, Latvia \\ ${ }^{2}$ Simon Kuznets Kharkiv National University of Economics, 9-A, Nauky Ave., Kharkiv, 61166, \\ Ukraine \\ ${ }^{3}$ Simon Kuznets Kharkiv National University of Economics, 9-A, Nauky Ave., Kharkiv, 61166, \\ Ukraine
}

\begin{abstract}
This article deals with the problem of providing the machinebuilding and metalworking industry in Latvia with labor resources capable of ensuring the innovative development of the industry. Imbalance in the labor market has been shown, the tasks facing the Latvian education system are identified, the importance of training and development of personnel of the machine-building and metalworking industry enterprises is pointed out. The importance of lifelong learning was noted, since the fourth industrial revolution, the aging of population and the extension of the active working age dictate need for constant adaptation of the skills and abilities of workers. The main activities of enterprise in the industry to attract the interest of young people to relevant professions are considered, a number of existing projects of training and development staff of engineering enterprises has been shown.
\end{abstract}

\section{Introduction}

Currently, Latvian economy is being transformed into a model of sustainable development, where one of the "driving forces" of country's economic development is to export of manufactured products and services, ability to compete in local and foreign markets. As important role in this process belongs to engineering and metalworking industries, since, firstly, this industry provides other sectors of the economy with machinery, production systems, components and related services, as well as technologies and knowledge necessary for these industries, secondly, the industry has a pronounced export orientation.

However, mechanical engineering and metalworking industry must deal with challenges which are relevant to industrial policy of Latvia as whole. Such challenges include, in particular, low labor productivity, labor costs and price competitiveness, imperfection of the innovation system, and the demographic situation. A lot of businesses are looking for innovative ways to improve efficiency and maintain competitive advantage in order to survive $[1,2,3]$. The reason why new and small businesses have become key players in the

*Corresponding author: jelena.lukjanova@isma.lv 
innovation process has been their ability to identify and exploit business opportunities that emerge because of technological, competitive and market developments $[4,5]$.

Under those conditions, provision of enterprises in the industry with staff required quantity and with appropriate staff and professional qualities is of particular importance. Successful innovation activity of enterprises is impossible without the constant adaptation of personal skills and professional competencies of employees [6].

The purpose of this article based on analysis of the situation on Latvian labor market, is to identify the most important tasks of the education system, and identify main activities at the state and sectoral level, the implementation of which will provide the mechanical engineering and metalworking industry with the necessary personnel capable of solving the tasks of the industry's innovative development.

\section{Materials and methods}

In this research authors made:

$\checkmark$ Data analysis of Economy Ministry of Latvia in economic trends, medium-term and long-term forecast of the labor market;

$\checkmark$ Analysis of the data of the Latvian Association of Mechanical Engineering and Metalworking about the situation in the industry, analysis as the result of the study on the identification of professional skills that industry workers should possess;

$\checkmark$ Analysis of projects for the training and advanced training for workers, in particular, the projects "Training of workers in mechanical engineering and metalworking", "Improving the professional competence of personnel", "Post-doctoral Research Aid";

$\checkmark$ Study experience of cooperation in the Association of Mechanical Engineering and Metalworking with schools and universities of Latvia.

\section{Results and discussion}

Machine building industry and metalworking has pronounced export orientation, average of $75-80 \%$ of the production is exported. In 2018 , the industry accounted for $18 \%$ of the total turnover of the manufacturing industry and $23 \%$ of the total exports of goods.

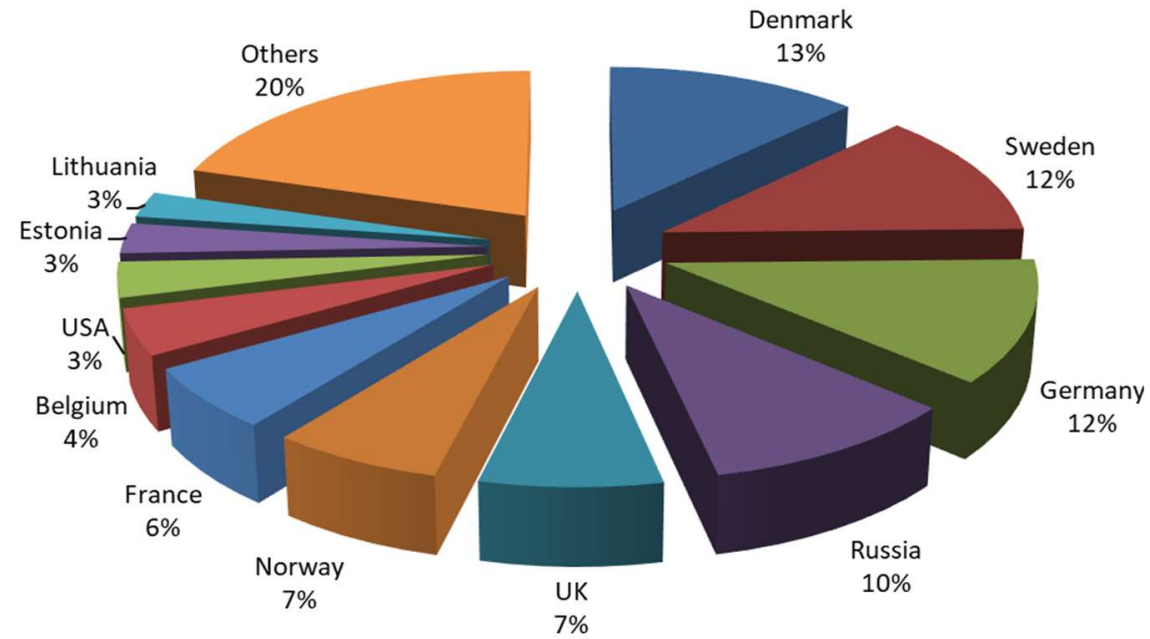

Fig. 1. Main export markets for the engineering and metalworking industries, \% [8]. 
In $2018,68.5 \%$ of metal-working products and $88.4 \%$ of engineering products were exported [7]. The export geography is wide - products of the Latvian engineering and metalworking industry were exported to about 100 countries.

In 2018, the main trading partners were Denmark, Germany, Sweden, Russia, Norway, United Kingdom and France (Figure 1). The volume of geography exports testifies to the competitiveness of goods produced in Latvia at the price, quality and delivery time. However, the mechanical engineering and metalworking industry must deal with challenges that are relevant to the industrial policy of Latvia as whole. Such challenges include low labor productivity, low innovative activity of enterprises, labor costs and price competitiveness, and the demographic situation.

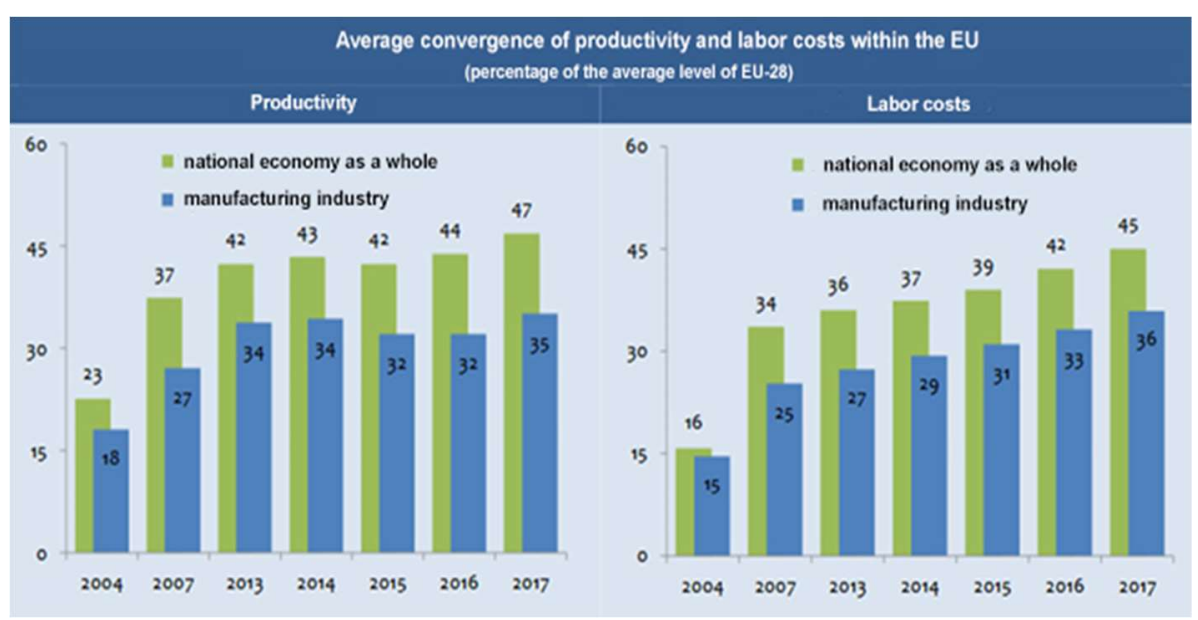

Fig. 2. Convergence of productivity and labor costs with the average level of the EU (percentage of the average level of EU-28) [9]

In 2017 , productivity in Latvia was $46.8 \%$ from EU average, it is one of the lowest average in EU. Level of productivity in manufacturing industry in EU countries is on average $17 \%$, and in the old EU member states (EU-15) it is $28 \%$ higher than the average of the national economy. However, in Latvia productivity in manufacturing industry is almost $20 \%$ behind the average for the national economy (Figure 2).

Increase of productivity is connected, first of all, with the ability of enterprises to carry out technological modernization and innovations, to raise the qualifications of staff, apply risk reduction and risk management tools [10]. In Latvia, labor costs make up $45 \%$ of the average costs in the EU, manufacturing industry even less - 36\%. However, within recent years, growth rate of labor costs has increased.

In the future, further approximation of Latvian indicators in EU average is expected, the convergence process is inevitable. At the same time, Latvia is an imbalance between the growth rates of productivity and labor costs, which threatens the competitiveness of Latvian entrepreneurs. To increase wages in Latvia was influenced by the increase in the minimum wage, desire of entrepreneurs to maintain highly skilled workers, decrease in unemployment, etc. Therefore, strengthening Latvia's competitiveness will be largely determined by the ability to reduce the productivity gap. The most important factor in productivity growth is innovation. Startups play a very important role in this area, and their importance in the economy is gradually growing [6].

According to Global Innovation Index 2018, Latvia is 34th in the Global Innovation Index. In seven categories of indicators in Latvia, the best indicator was in the category of creativity, where it occupies 23 rd place. In the category of market development, Latvia ranks 24 th, in the category of institutions - 31st, business development - 36th, infrastructure 
- 45th, knowledge and technology - 51st, human capital and research - 53rd [11]. Among the EU countries, Latvia is a moderate innovator (Figure 3).

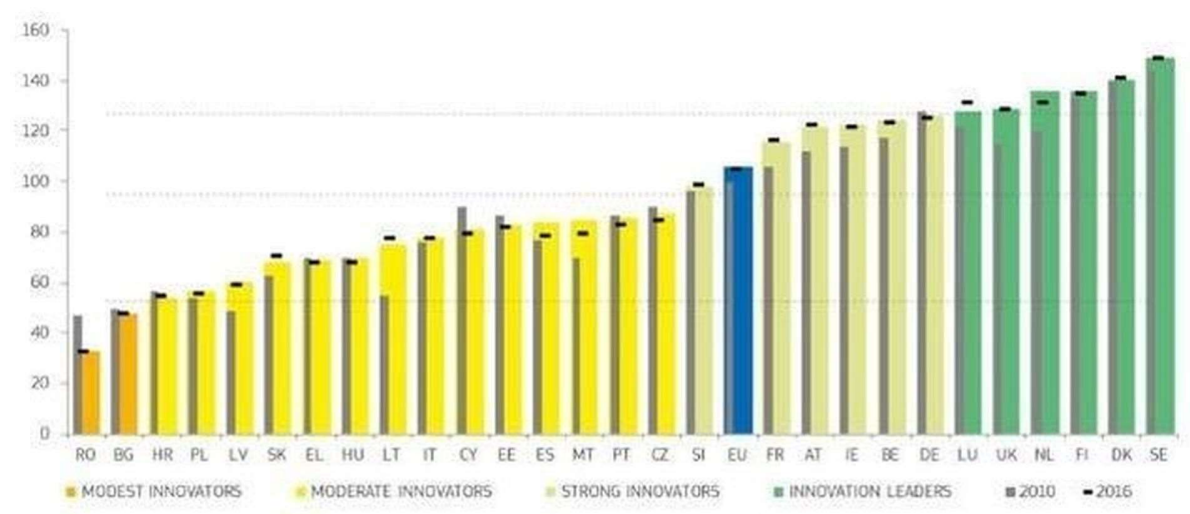

Fig.3 Rating of EU states according to the European Innovation Scoreboard 2018 [12]

The main documents regulating direction and development of the innovation policy in Latvia are: the main directions of the national industrial policy for 2014-2020, strategy of smart specialization, Latvian national development plan for 2014-2020, the strategy for the long-term development of Latvia until 2030, the main directions development of science, technology and innovation for 2014-2020. Also, basic document is European Union Development Strategy up to 2020 - Europe 2020, developed in 2010 by the European Commission. One of the three main development priorities in the Strategy is reasonable growth - the transition to an economy based of knowledge and innovation.

There is disproportion between the supply and demand of labor in the Latvian market there is oversupply of specialists in humanities and social sciences (in 2022 an overabundance of $\sim 10$ thousand people is predicted), there is shortage of highly qualified specialists in the natural sciences, information technologies and engineering sciences (In 2022 , a deficit is projected - 16 thousand people).

Medium term, the state will face a significant shortage of workers with vocational education (30 thousand people), among which a significant proportion will be specialists in the engineering and manufacturing fields. Significant number of young people entering to labor market without profession, in 2022 more than 25 thousand young people without profession will have problems with the employment.

Proportion of low-skilled workers is high. The existing imbalances in the labor market will be aggravated under the influence of demographic factors, namely: by 2022, the population of Latvia is expected to decline more than 60 thousand people. The most important production areas, including mechanical engineering, will experience a shortage of workers [13].

Current situation poses number of primary tasks for the Latvian education system, particular:

$\checkmark$ Improvement and development of the system of secondary vocational education to provide labor market with specialists of appropriate qualifications;

$\checkmark$ Increase number of students of universities and colleges who study the programs of natural and engineering sciences. In 2020, the number of graduates of relevant specialties should reach $27 \%$ of the total number of graduates of universities and colleges; 
$\checkmark$ More active involvement of the adult population in lifelong learning. The task is to increase the proportion of people involved in adult education (25-64 years) to $15 \%$ by 2020 [14].

For the engineering and metalworking industries, availability of qualified professionals is one of the top priorities. In 2017, the Association of Mechanical Engineering and Metalworking conducted a survey of the leaders of 30 industry enterprises on the skills needed in the future in connection with the introduction of Industry $4.0 .65 .5 \%$ of respondents noted that the employees of their enterprise lack specific knowledge, $57.6 \%$ of respondents indicated that the company needs staff training.

The main soft skills (soft skills) necessary for the introduction of Industry 4.0 are the ability to introduce innovations $(83.3 \%)$ and the desire to gain new knowledge $(70 \%)$ (Table 1). For an employee, professional competence is a fundamental element in the transition from the ability to be "hired" to the ability to "always find a job".

Table 1.Rating of professional skills which employees must possess mechanical engineering and metalworking industries for the introduction of Industry 4.0.

\begin{tabular}{|l|l|}
\hline $\begin{array}{l}\text { \% Interviewed } \\
\text { respondents }\end{array}$ & \multicolumn{1}{c|}{ Professional skills } \\
\hline $83.3 \%$ & Technical skills, including new technologies and new materials \\
\hline $80 \%$ & Competences in the field of electrical engineering and mechanics \\
\hline $80 \%$ & Robotic, including IT aspects of technology monitoring \\
\hline $70 \%$ & IT skills including software maintenance \\
\hline $56.7 \%$ & Knowledge management, including knowledge sharing and development \\
\hline $50 \%$ & Additional technologies, including 3D printing \\
\hline $46.7 \%$ & Processing and analyzing large amounts of data \\
\hline $36.7 \%$ & Confidentiality, including user rights, IT infrastructure \\
\hline $30 \%$ & Social skills, including collaboration and communication \\
\hline $20 \%$ & Media skills, including social networks, mobile devices \\
\hline Others & $\begin{array}{l}\text { Labor protection, functional equipment safety, decentralized process } \\
\text { management. }\end{array}$ \\
\hline
\end{tabular}

Fourth industrial revolution (Industry 4.0) makes new demands on the tasks and knowledge of workers. The formation of competences of future specialist should assume such an educational environment that can provide a combination of applied and fundamental training; vocational training and development; the ability to independently see the problem and find solution [1].

However, at present, level of training and qualifications of personnel in the engineering and metalworking industry lags behind the requirements of Industry 4.0. In this regard, in the industry, an important place is given to the training and advanced training of workers.

Currently, project of "Training of workers in the mechanical engineering and metalworking industry" is being implemented. The goal of the project is to provide training and advanced training for workers in the mechanical engineering and metalworking industry areas most important to the industry. This will help to increase productivity, as well as the development and introduction of new, improved products and technologies into production.

The agreement on the implementation of this project was signed between the Latvian Association of Mechanical Engineering and Metalworking and the Central Finance and Contracting Agency.

Another project aimed at improving the professional competence of employees is EU Foundation's project "Increasing the Professional Competence of Staff". The goal of the project is to eliminate the problem of non-compliance of the qualification of the labor force with the market requirements, increase the competitiveness of labor force and increase labor productivity. The program is funded by the European Social Fund and Latvian state, 
more than 25 million euros will be invested in it within six years - until December 31, 2022. Within the framework of this project, 71 educational programs are offered within the engineering and metalworking industry [17].

Challenge for Latvian innovation system is weak potential for commercialization of research results - an insufficient number of people employed in science and research, poorly developed and fragmented research and development infrastructure, as well as a small number of modernly equipped laboratories for the implementation of technological projects.

The implementation of the Post-doctoral Research Aid project is aimed at supporting scientific activities. This is an important financial tool of the European Regional Development Fund, aimed at enhancing the research potential and career development of young scientists. In the next 7 years, more than 60 million euros are available to young scientists in this project. [18].

Young scientists working in this field of mechanical engineering and metalworking can also take part in this project, as following areas are supported by the project:

- Basic or industrial research;

- Acquisition, verification and protection of rights to technology;

- Transfer of knowledge and technology;

- Development of competencies, international mobility and networking;

- Preparation of other research and innovative products.

The most important task of innovation development is to strengthen cooperation between enterprises and educational institutions, attracting interest of schoolchildren and students to obtaining the relevant knowledge, skills and competencies necessary for successful work in the field of mechanical engineering and metalworking in the context of the introduction of Industry 4.0.

As part of this task, Latvian Association of Mechanical Engineering and Metalworking is implementing the "Tehnobuss project", purpose of which is to more attractively and visually introduce 4-12 grade students to advanced technologies, educational opportunities and career development in the engineering and metalworking industries and to stimulate youth's interest in engineering sciences [19].

The project develops cooperation between educational institutions, employers and young people. In turn, cooperation between enterprises of the industry and students of technical specialties in the field of computer-aided design, drafting and design is implemented within the framework of the activities of the student design bureau. The idea of the student design bureau was launched and developed in the framework of the cluster project of Latvian Association of Mechanical Engineering and Metalworking, with the cooperation of the association with the Faculty of Transport and Mechanical Engineering of Riga Technical University.

\section{Conclusions}

In the reality of contemporary global economy, competition becomes one of the most important determinants of the market position of an enterprise [20-21].

One of the most serious challenges for the successful innovative development of machine-building and metal-working industry is problem of providing the industry with the necessary number of staff with relevant knowledge, skills and competencies. Development of competent mechanisms for overcoming discrepancies between the education system and the requirements for successful professional development of human potential in the engineering and metalworking industries remains topical.

Industry representatives are aware of the urgency of the problem and are actively involved in personnel training and development projects. However, it must be borne in 
mind that in order to successfully solve this problem, it is necessary to jointly apply efforts and cooperation of all stakeholders - state, research and educational institutions, professional organizations and entrepreneurs, as well as the employees themselves. This is the key to success.

\section{References}

1. M. Petrova, M. Tepavicharova, L. Boykova, E3S Web of Conferences, 41, 04017 (2018)

2. M. Petrova, N. Dekhtyar, O. Klok, O. Loseva, Problems and Perspectives in Management, 16:4, 259 (2018)

3. V. Koval, G. Duginets, O. Plekhanova, A. Antonov, M. Petrova, Entrepreneurship and Sustainability Issues, 6, 4 (2019)

4. T. Odinokova, M. Bozhinova, M. Petrova, E3S Web Conferences, 41, 04015 (2018)

5. M. Petrova, O. Sushchenko, I. Trunina, N. Dekhtyar, IEEE First International Conference on System Analysis \& Intelligent Computing (SAIC-2018), 256 (2018)

6. R. Pukala, E. Sira, R. Vavrek, Marketing and Management of Innovations, 3, 153 (2018)

7. Ekonomikas ministrija (2019)

8. Ekonomikas ministrija (2018)

9. R. Pukala, Engineering Management in Production and Services, 8:3, 43 (2016)

10. Global Innovation Index (2018)

11. European Innovation Scoreboard (2018)

12. Ekonomikas ministrija (2016)

13. Eкоnоmikas ministrija. Informatīvais ziṇojums par darba tirgus vidēja un ilgtermiña prognozèm (2018)

14. Mašīnuūves un metālapstrādes Rūpniecības Asociācija (2017)

15. The third call for research applications under the activity "Post-doctoral Research Aid" (2019)

16. Project Tehnobuss (2019)

17. Sv. Labunska, M. Petrova, O. Prokopishyna, Economic Annals - XXI, 165:5-6, 13 (2017)

18. Y. Dyachenko, N. Nenkov, M. Petrova, I. Skarga-Bandurova, O. Soloviov, Elsevier, 26, 130 (2018) 